\title{
Article \\ Efficacy of Empiric Antibiotic Coverage in Community-Acquired Pneumonia Associated with Each Atypical Bacteria: A Meta-Analysis
}

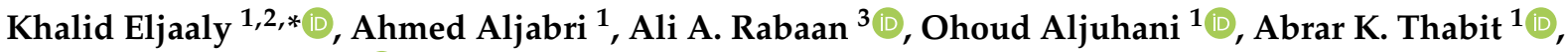 \\ Mohannad Alshibani ${ }^{1}\left(\right.$ and Thamer A. Almangour ${ }^{4}$ \\ 1 Department of Pharmacy Practice, Faculty of Pharmacy, King Abdulaziz University, \\ Jeddah 21589, Saudi Arabia; amaljabri@kau.edu.sa (A.A.); oaljuhani@kau.edu.sa (O.A.); \\ akthabit@kau.edu.sa (A.K.T.); malshibani@kau.edu.sa (M.A.) \\ 2 Department of Pharmacy Practice and Science, College of Pharmacy, University of Arizona, \\ Tucson, AZ 85724, USA \\ 3 Molecular Diagnostic Laboratory, Johns Hopkins Aramco Healthcare, Dhahran 31311, Saudi Arabia; \\ ali.rabaan@jhah.com \\ 4 Department of Clinical Pharmacy, College of Pharmacy, King Saud University, Riyadh 11451, Saudi Arabia; \\ talmangour@ksu.edu.sa \\ * Correspondence: keljaaly@kau.edu.sa
}

\section{check for} updates

Citation: Eljaaly, K.; Aljabri, A.; Rabaan, A.A.; Aljuhani, O.; Thabit, A.K.; Alshibani, M.; Almangour, T.A. Efficacy of Empiric Antibiotic Coverage in Community-Acquired Pneumonia Associated with Each Atypical Bacteria: A Meta-Analysis. J. Clin. Med. 2021, 10, 4321. https:// doi.org/10.3390/jcm10194321

Academic Editors: Kazunobu Ouchi and David Barnes

Received: 11 August 2021

Accepted: 17 September 2021

Published: 23 September 2021

Publisher's Note: MDPI stays neutral with regard to jurisdictional claims in published maps and institutional affiliations.

Copyright: (c) 2021 by the authors. Licensee MDPI, Basel, Switzerland. This article is an open access article distributed under the terms and conditions of the Creative Commons Attribution (CC BY) license (https:/ / creativecommons.org/licenses/by/ $4.0 /)$.
Abstract: The benefit of empiric coverage for community-acquired pneumonia (CAP) for atypical bacteria is controversial. This meta-analysis purpose was to compare the clinical failure rate between adults who empirically received atypical coverage versus those who did not. We searched PubMed and EMBASE for randomized controlled trials (RCTs), comparing the clinical failure rate of CAP associated with individual atypical bacteria between adults who received empiric atypical coverage versus those who did not. Risk differences (RDs) with 95\% confidence intervals (CIs) were calculated using random-effects models. Eight double-blind RCTs (65 patients with Legionella spp., 176 patients with M. pneumoniae, and 78 patients with C. pneumoniae) were included in the meta-analysis. The rate of clinical failure was significantly lower with empiric atypical coverage in CAP associated with Legionella spp. (RD, $-42.6 \% ; 95 \% \mathrm{CI},-69.8 \%$ to $-15.4 \% ; p$-value $=0.002 ; \mathrm{I}^{2}=0 \%$ ) and Mycoplasma pneumoniae (RD, $-9.5 \% ; 95 \% \mathrm{CI},-18.9 \%$ to $-0.1 \%$; $p$-value $=0.048 ; \mathrm{I}^{2}=0 \%$ ), but not with Chlamydia pneumoniae (RD, 7.1\%; 95\% CI, $-9.0 \%$ to $23.1 \%$; $p$-value $=0.390 ; \mathrm{I}^{2}=0 \%$ ). This meta-analysis of RCTs found that empiric atypical coverage decreased the clinical failure rate of CAP associated with Legionella spp. and M. pneumoniae, but not with C. pneumoniae.

Keywords: atypical bacteria; legionella; mycoplasma; chlamydia; antibiotic

\section{Introduction}

Community-acquired pneumonia (CAP) is one of the most common infections worldwide and is associated with significant morbidity and mortality [1-3]. Major causative pathogens include both typical bacteria, such as Streptococcus pneumoniae and Haemophilus influenzae, and atypical bacteria, such as Legionella spp., Mycoplasma pneumoniae, and Chlamydophila pneumoniae. The international incidence of atypical bacteria in patients with CAP is estimated to be $22 \%$ and varies according to the geographical region. For instance, the incidence of atypical bacteria in the US is approximately $4 \%$, whereas in China, the incidence is approximately $40 \%$, exceeding that of $S$. pneumoniae $[4,5]$. The true incidence is likely underestimated since it is not a standard of care in many countries to microbiologically identify these pathogens in respiratory cultures especially in the outpatient setting. Considering the undistinguished clinical features between atypical vs. typical pathogens and the lack of an accurate and rapid diagnostic tool for pathogen identification, starting patients with CAP empirically on an antibiotic with atypical coverage might be warranted. 
Atypical bacteria are covered by either macrolides, doxycycline, or fluoroquinolones. It is still debatable whether CAP patients must receive empiric antibiotic therapy for atypical bacteria [6]. The potential risk of side effects, drug-drug interactions, microbial resistance, and cost of adding anti-bacterial coverage against atypical bacteria should be weighed versus the risk of worse clinical outcomes with missing this antibacterial activity [6-9]. Several major guidelines recommended adding empiric atypical coverage for hospitalized patients, particularly those with moderate to high severity [1-3]. The finding from a recent meta-analysis of randomized controlled trials (RCTs) supports this recommendation, as significantly more patients clinically failed therapy in the group receiving antibiotics lacking atypical bacterial activity [6]. However, it is unclear which atypical bacteria benefited from the empiric coverage and whether the difference found was due to clinical failure of bacteria other than atypical bacteria. The objective of this meta-analysis was to compare the difference in the rate of clinical failure of CAP associated with each atypical bacteria between adults who empirically received atypical bacterial coverage versus those who did not.

\section{Materials and Methods}

This systematic review and meta-analysis was performed according to the Preferred Reporting Items for Systematic Reviews and Meta-Analyses (PRISMA) guideline.

\subsection{Search Strategy and Study Selection Criteria}

We searched the EMBASE and PubMed bibliographic databases until 21 March 2021. Two authors independently extracted the data and screened the literature without restricting language or date. The search strategy is provided in Appendix A (Table A1). RCTs reporting clinical efficacy of empiric atypical coverage (with fluoroquinolones, macrolides, or doxycycline) versus no coverage (i.e., $\beta$-lactams) in adults with CAP caused by individual atypical bacteria (Legionella spp., M. pneumoniae, and C. pneumoniae) were included. RCTs of pediatrics and those not reporting clinical failure of CAP caused by individual atypical bacteria were excluded.

\subsection{Outcomes, Data Analysis, and Risk of Bias}

The study outcome was the rate of clinical failure among each atypical bacteria. Mantel-Haenszel risk differences (RDs) with 95\% confidence intervals (CIs) were calculated using random-effects models, and heterogeneity $\left(\mathrm{I}^{2}\right)$ was assessed using Cochran's $\mathrm{Q}$ test. The study quality was assessed via the Cochrane risk of bias tool for RCTs (low, unclear, or high). All analyses were done using the Comprehensive Meta-Analysis v.3 software (Biostat, Englewood, NJ, USA).

\section{Results}

\subsection{Search Results and Study Characteristics}

The search process revealed 595 articles, and a total of eight RCTs were included eventually as shown in Figure 1. A total of 65 patients with Legionella spp., 176 patients with M. pneumoniae, and 78 patients with C. pneumoniae were included. The diagnosis of atypical bacteria was based on serology. The characteristics of included studies are provided in Table 1, and the study quality assessment is provided in Table 2. All included studies were published [10-16] except one (Grunenthal 2000; study report KF5501/16). All were multi-centered and double-blinded RCTs. All RCTs were multicontinental (except one), industry-sponsored (except one), and included non-severe CAP (except two included CAP of any severity). The antibiotics used in the empiric atypical coverage arm of all RCTs were fluoroquinolones, but one study also used erythromycin. The duration of antibiotic therapy ranged from 5-14 days. 


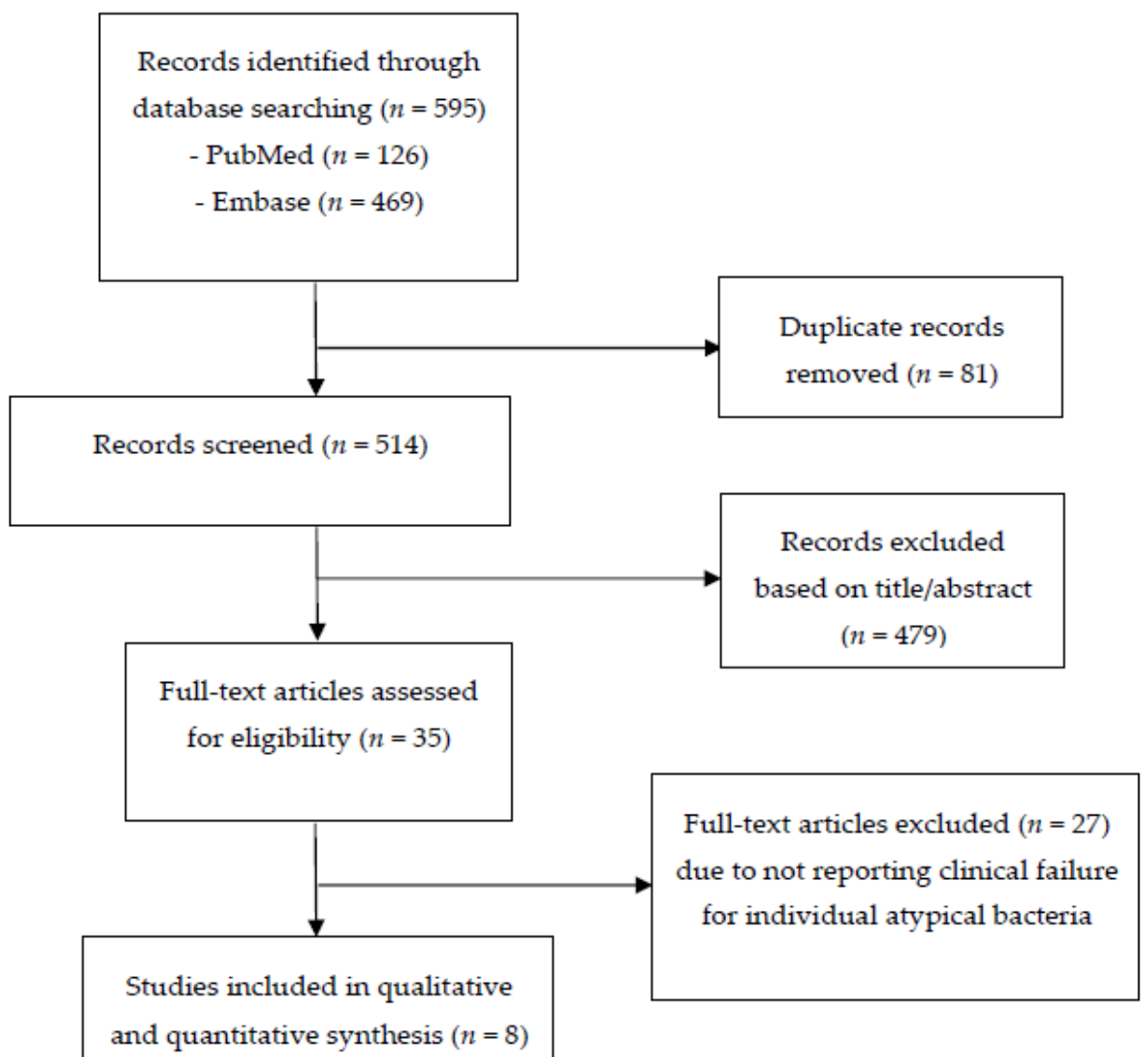

Figure 1. Flow diagram of the study selection process.

Table 1. Characteristics of the included studies.

\begin{tabular}{|c|c|c|c|c|c|c|c|c|c|c|}
\hline Study & $\begin{array}{l}\text { Study } \\
\text { Period }\end{array}$ & Design & Location & $\begin{array}{c}\begin{array}{c}\text { Funding } \\
\text { Source } \\
\text { (Manufactured } \\
\text { Drug) }\end{array} \\
\end{array}$ & Legionella spp. & M. Pneumoniae & C. Pneumoniae & $\begin{array}{l}\text { Characteristics } \\
\text { of Community- } \\
\text { Acquired } \\
\text { Pneumonia }\end{array}$ & $\begin{array}{l}\text { Atypical vs. } \\
\text { Non-Atypical } \\
\text { Regimen }\end{array}$ & $\begin{array}{l}\text { Duration of } \\
\text { Therapy } \\
\text { (Days) }\end{array}$ \\
\hline Aubier 1998 [10] & 1991-1992 & $\begin{array}{l}\text { Superiority, } \\
\text { double-blind, } \\
\text { RCT }\end{array}$ & $\begin{array}{l}55 \text { sites in } 3 \\
\text { countries } \\
\text { (Europe, } \\
\text { South Africa) }\end{array}$ & Non-industry & 1 vs. 4 & 1 vs. 3 & NA & $\begin{array}{l}\text { Hospitalized, } \\
\text { mild-moderate }\end{array}$ & $\begin{array}{l}\text { Sparfloxacin PO } \\
400 \mathrm{mg} \text { q24h, } \\
\text { then } 200 \mathrm{mg} \text { q24h } \\
\text { vs. amoxicillin } \\
1 \mathrm{~g} \text { PO q24h }\end{array}$ & $10-14$ \\
\hline Carbon 1992 [11] & 1989-1990 & $\begin{array}{l}\text { Superiority, } \\
\text { double-blind, } \\
\text { RCT }\end{array}$ & $\begin{array}{l}27 \text { sites in } \\
\text { France }\end{array}$ & $\begin{array}{c}\text { Industry } \\
\text { (temafloxacin) }\end{array}$ & 3 vs. 2 & 2 vs. 1 & NA & $\begin{array}{l}\text { Hospitalized, } \\
\text { mild-moderate }\end{array}$ & $\begin{array}{l}\text { Temafloxacin } 600 \\
\text { mg PO q12h vs. } \\
\text { amoxicillin } \\
500 \text { mg PO q } 8 \mathrm{~h}\end{array}$ & 10 \\
\hline Leophonte 2004 [12] & 1998-1999 & $\begin{array}{l}\text { Superiority, } \\
\text { double-blind, } \\
\text { RCT }\end{array}$ & $\begin{array}{l}102 \text { sites in } 3 \\
\text { countries } \\
\text { (Europe, } \\
\text { South Africa) }\end{array}$ & $\begin{array}{c}\text { Industry } \\
\text { (gemifloxacin) }\end{array}$ & 5 vs. 6 & 16 vs. 18 & 5 vs. 1 & $\begin{array}{c}>90 \% \\
\text { hospitalized, } \\
\text { suspected } \\
\text { pneumococcal } \\
\text { mild-moderate }\end{array}$ & $\begin{array}{c}\text { Gemifloxacin } 320 \\
\text { mg PO q24h vs. } \\
\text { amoxicillin/clav } \\
1.2 \mathrm{~g} \mathrm{PO} \mathrm{q8h}\end{array}$ & 7 vs. 10 \\
\hline Lode 1995 [13] & 1990-1992 & $\begin{array}{l}\text { Superiority, } \\
\text { double-blind, } \\
\text { RCT }\end{array}$ & $\begin{array}{c}124 \text { sites in } 9 \\
\text { countries } \\
\text { (Europe, Israel) }\end{array}$ & $\begin{array}{c}\text { Industry } \\
\text { (sparfloxacin) }\end{array}$ & 8 vs. 2 & 20 vs. 12 & 8 vs. 3 & $\begin{array}{l}\text { Hospitalized } \\
\text { and outpatients, } \\
\text { mild-moderate }\end{array}$ & $\begin{array}{l}\text { Sparfloxacin PO } \\
400 \mathrm{mg} \text { once, } \\
\text { then } 200 \mathrm{mg} \text { q24h } \\
\text { or erythromycin } \\
1 \mathrm{~g} \text { PO q12h vs. } \\
\text { amoxicillin/clav } \\
625 \mathrm{mg} \text { PO q } 8 \mathrm{~h}\end{array}$ & $7-14$ \\
\hline Lode 2004 [14] & 1997-1998 & $\begin{array}{l}\text { Superiority, } \\
\text { double-blind, } \\
\text { RCT }\end{array}$ & $\begin{array}{c}73 \text { sites in } 16 \\
\text { countries } \\
\text { (mostly Europe) }\end{array}$ & $\begin{array}{c}\text { Industry } \\
\text { (gatifloxacin) }\end{array}$ & 3 vs. 1 & 9 vs. 7 & NA & $\begin{array}{l}\text { Hospitalized, } \\
\text { mild-moderate }\end{array}$ & $\begin{array}{l}\text { Gatifloxacin } 400 \\
\mathrm{mg} \text { PO q24h vs. } \\
\text { amoxicillin/clav } \\
625 \mathrm{mg} \text { PO q } 8 \mathrm{~h}\end{array}$ & 5-10 \\
\hline Petitpretz 2001 [15] & 1997-1998 & $\begin{array}{l}\text { Superiority, } \\
\text { double-blind, } \\
\text { RCT }\end{array}$ & $\begin{array}{l}82 \text { sites in } 20 \\
\text { countries } \\
\text { (Europe, South } \\
\text { America, } \\
\text { Australia, } \\
\text { Africa) }\end{array}$ & $\begin{array}{c}\text { Industry } \\
\text { (moxifloxacin) }\end{array}$ & 1 vs. 2 & 7 vs. 13 & 5 vs. 1 & $\begin{array}{c}79 \% \\
\text { hospitalized, } \\
\text { mild-moderate }\end{array}$ & $\begin{array}{l}\text { Moxifloxacin } 400 \\
\text { mg PO q24h vs. } \\
\text { amoxicillin } \\
1 \text { g PO q } 8 \mathrm{~h}\end{array}$ & 10 \\
\hline Tremolieres 1998 [16] & 1995-1996 & $\begin{array}{l}\text { Superiority, } \\
\text { double-blind, } \\
\text { RCT }\end{array}$ & $\begin{array}{l}44 \text { sites in } \\
\text { Europe, South } \\
\text { Africa, } \\
\text { Costa Rica }\end{array}$ & $\begin{array}{c}\text { Industry } \\
\text { (trovafloxacin) }\end{array}$ & 6 vs. 6 & 16 vs. 14 & 22 vs. 26 & $\begin{array}{c}75 \% \\
\text { hospitalized, } \\
\text { any severity }\end{array}$ & $\begin{array}{l}\text { Trovafloxacin } 200 \\
\text { mg PO q24h vs. } \\
\text { amoxicillin } \\
1 \mathrm{~g} \mathrm{PO} \mathrm{q} 8 \mathrm{~h}\end{array}$ & 7-10 \\
\hline $\begin{array}{l}\text { Grunenthal } 2000 \\
\text { (unpublished; } \\
\text { KF5501/16) }\end{array}$ & 1999-2000 & $\begin{array}{l}\text { Superiority, } \\
\text { double-blind, } \\
\text { RCT }\end{array}$ & $\begin{array}{c}132 \text { sites, } \\
\text { multinational }\end{array}$ & $\begin{array}{c}\text { Industry } \\
\text { (gatifloxacin) }\end{array}$ & 6 vs. 9 & 17 vs. 20 & 4 vs. 3 & $\begin{array}{l}\text { Hospitalized, } \\
\text { any severity }\end{array}$ & $\begin{array}{l}\text { Gatifloxacin } 400 \\
\text { mg PO q24h vs. } \\
\text { amoxicillin } \\
1 \text { g PO q8h }\end{array}$ & $7-10$ \\
\hline
\end{tabular}


Table 2. Quality assessment of the included studies.

\begin{tabular}{|c|c|c|c|c|c|c|c|}
\hline \multirow[b]{2}{*}{ Study } & \multicolumn{2}{|c|}{ Selection Bias } & \multirow{2}{*}{$\begin{array}{c}\begin{array}{c}\text { Performance } \\
\text { Bias }\end{array} \\
\text { Blinding of } \\
\text { Participants } \\
\text { and Personnel }\end{array}$} & \multirow{2}{*}{$\begin{array}{c}\text { Detection Bias } \\
\text { Blinding of } \\
\text { Outcome } \\
\text { Assessment }\end{array}$} & \multirow{2}{*}{$\begin{array}{c}\text { Attrition Bias } \\
\text { Incomplete } \\
\text { Outcome Data }\end{array}$} & \multirow{2}{*}{$\begin{array}{c}\begin{array}{c}\text { Reporting } \\
\text { Bias }\end{array} \\
\text { Selective } \\
\text { Reporting }\end{array}$} & \multirow{2}{*}{$\begin{array}{l}\text { Other Bias } \\
\text { Other Bias }\end{array}$} \\
\hline & $\begin{array}{l}\text { Random } \\
\text { Sequence } \\
\text { Generation }\end{array}$ & $\begin{array}{l}\text { Allocation } \\
\text { Concealment }\end{array}$ & & & & & \\
\hline Aubier 1998 [10] & $?$ & $?$ & + & + & - & + & + \\
\hline Carbon 1992 [11] & $?$ & $?$ & + & + & - & + & - \\
\hline Leophonte 2004 [12] & $?$ & $?$ & + & + & - & - & $?$ \\
\hline Lode 1995 [13] & $?$ & $?$ & + & + & + & + & $?$ \\
\hline Lode 2004 [14] & + & + & + & + & + & + & $?$ \\
\hline Petitpretz 2001 [15] & + & + & + & + & - & + & $?$ \\
\hline Tremolieres 1998 [16] & $?$ & $?$ & + & + & + & + & $?$ \\
\hline $\begin{array}{c}\text { Grunenthal } 2000 \\
\text { (unpublished; } \\
\text { KF5501/16) }\end{array}$ & $?$ & $?$ & + & + & + & + & $?$ \\
\hline
\end{tabular}

+: low risk of bias, ?: unclear risk of bias, -: high risk of bias.

\subsection{Study Outcomes}

The rate of clinical failure was significantly lower with empiric atypical coverage in patients with Legionella spp. (RD, $-42.6 \% ; 95 \% \mathrm{CI},-69.8 \%$ to $-15.4 \%$; $p$-value $=0.002$; $\mathrm{I}^{2}=0 \%$ ) and M. pneumoniae (RD, $-9.5 \% ; 95 \% \mathrm{CI},-18.9 \%$ to $-0.1 \% ; p$-value $=0.048 ; \mathrm{I}^{2}=0 \%$ ) (Figure 2). There was no significant difference in rate of clinical failure in patients with C. pneumoniae (RD, $7.1 \%$; $95 \%$ CI, $-9.0 \%$ to $23.1 \%$; $p$-value $=0.390 ; \mathrm{I}^{2}=0 \%$ ).

\begin{tabular}{|c|c|c|c|c|c|c|c|c|}
\hline \multirow[t]{2}{*}{ Study name } & \multirow[t]{2}{*}{ Bacteria Type } & \multicolumn{2}{|c|}{ Events / Total } & \multirow[b]{2}{*}{$\begin{array}{c}\text { Relative } \\
\text { weight }\end{array}$} & \multirow[b]{2}{*}{$\begin{array}{l}\text { MH risk } \\
\text { difference }\end{array}$} & \multicolumn{2}{|c|}{ atistics for each study } & \multirow[b]{2}{*}{ p-Value } \\
\hline & & Atypical & Non-atypical & & & $\begin{array}{l}\text { Lower } \\
\text { limit }\end{array}$ & $\begin{array}{l}\text { Upper } \\
\text { limit }\end{array}$ & \\
\hline Grunenthal unpublished & C. pneumonise & $0 / 4$ & $0 / 3$ & 14.87 & 0.000 & -0.417 & 0.417 & 1.000 \\
\hline Leophonte 2004 [12] & C. pneumonise & $0 / 5$ & $0 / 1$ & 6.33 & 0.000 & -0.640 & 0.640 & 1.000 \\
\hline Lode 1995 [13] & C. pneumonise & $0 / 8$ & $1 / 3$ & 10.47 & -0.333 & -0.831 & 0.164 & 0.189 \\
\hline Petitpretz 2001 [15] & C. pneumonise & $1 / 5$ & $0 / 1$ & 5.39 & 0.200 & .0 .493 & 0.893 & 0.572 \\
\hline \multirow[t]{2}{*}{ Tremolieres 1998 [18] } & C. preumonise & $5 / 22$ & $2 / 28$ & 62.94 & 0.150 & -0.053 & 0.353 & 0.148 \\
\hline & & & & & 0.071 & -0.090 & 0.231 & 0.390 \\
\hline Aubier 1998 [10] & Legionells & $0 / 1$ & $3 / 4$ & 9.27 & -0.750 & -1.472 & -0.028 & 0.042 \\
\hline Carbon 1992 [11] & Legionella & $0 / 3$ & $1 / 2$ & 10.55 & -0.500 & $-1,152$ & 0.152 & 0.133 \\
\hline Grunenthal unpublished & Legionells & $1 / 6$ & $2 / 9$ & 16.85 & -0.056 & -0.459 & 0.348 & 0.787 \\
\hline Leophonte 2004 [12] & Legionella & $1 / 5$ & $2 / 6$ & 13.28 & -0.133 & -0.648 & 0.382 & 0.812 \\
\hline Lode $1995[13]$ & Legionella & $0 / 8$ & $2 / 2$ & 15.52 & -1.000 & -1.447 & -0.553 & 0.000 \\
\hline Lode 2004 [14] & Legionella & $0 / 3$ & $0 / 1$ & 9.98 & 0.000 & -0.682 & 0.682 & 1.000 \\
\hline Petitpretz 2001 [15] & Legionells & $0 / 1$ & $1 / 2$ & 7.73 & -0.500 & -1.325 & 0.325 & 0.235 \\
\hline \multirow[t]{2}{*}{ Tremolieres 1998 [18] } & Legionella & $0 / 8$ & $3 / 8$ & 18.44 & -0.500 & -0.917 & -0.083 & 0.019 \\
\hline & & & & & .0 .428 & -0.898 & -0.154 & 0.002 \\
\hline Aubier 1998 [10] & M. pneumonise & $0 / 1$ & $1 / 3$ & 1.52 & -0.333 & -1.098 & 0.432 & 0.393 \\
\hline Carbon 1992 [11] & M. pneumonise & $0 / 2$ & $0 / 1$ & 1.85 & 0.000 & -0.733 & 0.733 & 1.000 \\
\hline Grunenthal unpublished & M. pneumonise & $2 / 17$ & $5 / 20$ & 14.93 & -0.132 & -0.370 & 0.112 & 0.287 \\
\hline Leophonte 2004 [12] & M. pneumonise & $1 / 18$ & $2 / 18$ & 25.28 & -0.049 & .0 .236 & 0.139 & 0.811 \\
\hline Lode $1995[13]$ & M. pneumonise & $2 / 20$ & $2 / 12$ & 14.38 & -0.067 & .0 .315 & 0.182 & 0.599 \\
\hline Lode 2004 [14] & M. pneumonise & $0 / 9$ & $2 / 7$ & 7.31 & .0 .286 & .0 .634 & 0.083 & 0.108 \\
\hline Petitpretz 2001 [15] & M. pneumonise & $0 / 7$ & $1 / 13$ & 18.33 & .0 .077 & .0 .310 & 0.158 & 0.518 \\
\hline \multirow[t]{2}{*}{ Tremolieres 1998 [18] } & M. pneumoniae & $1 / 18$ & $2 / 14$ & 18.83 & -0.080 & .0 .299 & 0.138 & 0.471 \\
\hline & & & & & -0.095 & -0.189 & -0.001 & 0.048 \\
\hline
\end{tabular}

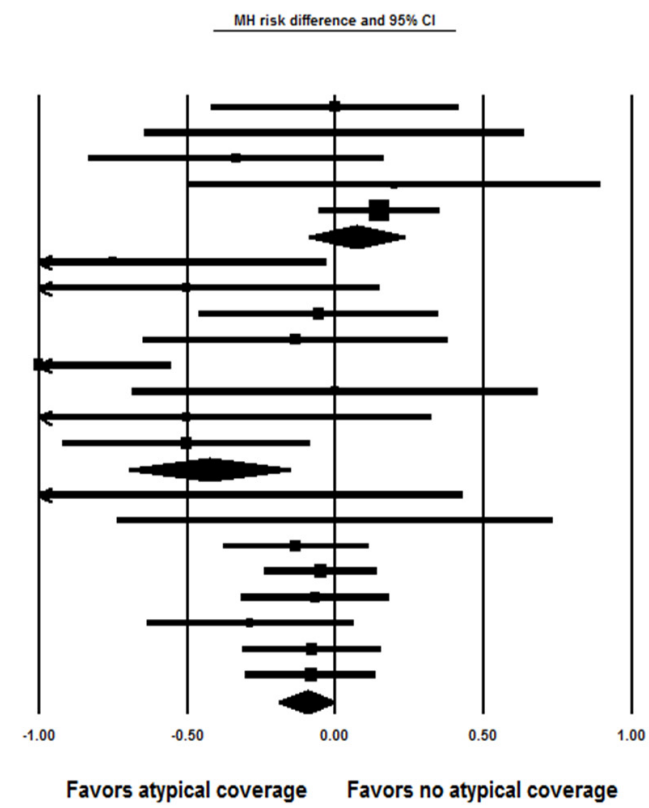

Figure 2. Forest plot showing the risk differences of clinical cure of community-acquired pneumonia associated with each atypical bacteria between adults who empirically received atypical bacterial coverage versus those who did not use random-effects models. Central vertical line, "no difference" point between the two groups; horizontal line, 95\% confidence interval; squares, risk differences; diamonds, pooled risk differences. CI, confidence interval; MH, Mantel-Haenszel.

\section{Discussion}

Our meta-analysis main finding is that the rates of clinical failure of treating Legionella spp. and M. pneumoniae were significantly lower in patients treated with antibiotics with atypical bacterial coverage compared to patients treated with antibiotics lacking atypical bacterial activity. The rate of clinical failure of treating $C$. pneumoniae was not significantly different between the two arms. The antibiotics with atypical coverage used in all the RCTs were fluoroquinolones except for one study, which used erythromycin. Although it was not 
included as an outcome in our meta-analysis, it is important to consider the adverse reactions of agents used for atypical bacteria. These reactions were assessed in the previous meta-analyses, and it depends on the antibiotic type used to cover atypical bacteria. The inclusion of RCTs improves the internal validity of the meta-analysis. In observational studies, the arm with atypical coverage would likely include the sicker patients in addition to other confounders in non-randomized studies. Moreover, all the included studies were multicenter and multicontinental, which also improves the external validity. Another strength is that all the included RCTs were double-blinded. The majority of the included patients had mild to moderate CAP. Including patients with severe infection could potentially increase the rate of clinical failure in the arm lacking atypical bacterial activity. This is particularly relevant to infections due to M. pneumoniae and C. pneumoniae, since mild infections are generally self-limiting, and including them could dilute the difference in the rates of clinical failure between the two arms.

Historically, the addition of an antibiotic with atypical coverage to a $\beta$-lactam for the management of CAP has been an area of debate. The cluster-RCT by Postma et al. found $\beta$-lactams monotherapy to be non-inferior to $\beta$-lactams-macrolide combination therapy or fluoroquinolone monotherapy with respect to 90 day mortality in patients admitted to non-intensive care unit wards [17]. This study deviated from the assigned empiric $\beta$-lactam monotherapy by allowing addition of empiric coverage of atypical bacteria to $\beta$-lactams, and it did not assess the rate of clinical failure. Major current guidelines recommend starting empiric regimens that include atypical coverage [1,2]. Moreover, a recent meta-analysis of RCTs has shown that starting hospitalized CAP patients on guideline-concordant empiric antibiotics with atypical coverage was associated with a significant reduction in the rate of clinical failure [6]. However, it was unknown if the difference in efficacy in this metaanalysis was due to the eradication of atypical bacteria versus other bacteria. The results of our meta-analysis are consistent with the guidelines recommendations and confirmed the benefits of starting empiric atypical coverage for patients with CAP. Some clinicians in some countries may not prefer routine empiric coverage of atypical bacteria in CAP patients, especially in areas with a low incidence of atypical pathogens. They may prefer the individualization of empiric therapy based on risk factors. However, more studies are needed, as limited data are available for risk factors for atypical bacteria. Risk factors for infection with Legionella spp. include age $>50$ years, diabetes, chronic obstructive pulmonary disease (COPD), smoking, and immunosuppression [18]. For M. pneumoniae, young age and crowded settings can increase the risk of contracting this pathogen [19].

The clinical failure rate of treating C. pneumoniae was not different between the two arms in this meta-analysis. This result should be interpreted carefully, since patients in the included trials had mild-moderate infection, and studies have shown that mild CAP infection due to M. pneumoniae and C. pneumoniae in many cases are self-limiting and patients improved spontaneously [20]. Unlike M. pneumoniae and C. pneumoniae, CAP due to Legionella Spp. is usually more severe and has significant mortality if left untreated [18]. Interestingly, studies of children showed that antibiotics for mild M. pneumoniae CAP decreased the morbidity and shortened the symptom duration [21]. However, the Infectious Disease Society of America guidelines for CAP stated that "The evidence to support specific treatment of these microorganisms in adults is lacking" [22].

\section{Conclusions}

Our meta-analysis of double-blind RCTs of adults, mostly with mild to moderate severity of infection, found a significantly lower rate of clinical failure with empiric atypical coverage in CAP associated with Legionella spp. and M. pneumoniae but not with C. pneumoniae. These findings generally support including empiric atypical bacterial coverage for CAP. Future studies should compare fluoroquinolones versus macrolides for CAP due to Legionella spp. and M. pneumoniae. 
Author Contributions: Conceptualization, K.E., A.A., A.K.T. and T.A.A.; methodology, K.E., O.A., M.A. and T.A.A.; formal analysis, K.E. and T.A.A.; investigation, K.E., A.A.R. and T.A.A.; data curation, K.E., A.A.R. and T.A.A.; writing-original draft preparation, K.E., A.A., O.A. and A.A.R.; writing-review and editing, T.A.A., M.A. and A.K.T.; visualization, K.E., A.A. and T.A.A.; supervision, K.E.; project administration, K.E. All authors have read and agreed to the published version of the manuscript.

Funding: This research received no external funding.

Institutional Review Board Statement: Not applicable.

Informed Consent Statement: Not applicable.

Data Availability Statement: Not applicable.

Conflicts of Interest: The authors declare no conflict of interest.

\section{Appendix A}

Table A1. Search Strategy.

\begin{tabular}{cc}
\hline Database/Search Dates & Search Strategy \\
\hline $\begin{array}{c}\text { PubMed / MEDLINE, National Library of Medicine } \\
\text { (Searched until 21 March 2021) }\end{array}$ & \#1-“Macrolides”[Mesh] OR “Fluoroquinolones”[Mesh] OR \\
“Doxycycline”[Mesh] \\
\#2-“beta-Lactams”[Mesh] \\
\#3-pneumonia[Mesh]
\end{tabular}

\section{References}

1. Metlay, J.P.; Waterer, G.W.; Long, A.C.; Anzueto, A.; Brozek, J.; Crothers, K.; Cooley, L.A.; Dean, N.C.; Fine, M.J.; Flanders, S.A.; et al. Diagnosis and Treatment of Adults with Community-acquired Pneumonia. An Official Clinical Practice Guideline of the American Thoracic Society and Infectious Diseases Society of America. Am. J. Respir. Crit. Care Med. 2019, 200, e45-e67. [CrossRef] [PubMed]

2. Pneumonia in Adults: Diagnosis and Management. Available online: https://www.nice.org.uk/guidance/cg191 (accessed on 23 July 2019).

3. Woodhead, M.; Blasi, F.; Ewig, S.; Garau, J.; Huchon, G.; Ieven, M.; Ortqvist, A.; Schaberg, T.; Torres, A.; van der Heijden, G.; et al. Guidelines for the management of adult lower respiratory tract infections-Summary. Clin. Microbiol. Infect. 2011, 17 (Suppl. 6), 1-24. [CrossRef] [PubMed]

4. Arnold, F.W.; Summersgill, J.T.; Ramirez, J.A. Role of Atypical Pathogens in the Etiology of Community-Acquired Pneumonia. Semin. Respir. Crit. Care Med. 2016, 37, 819-828. [CrossRef] [PubMed]

5. Tao, L.L.; Hu, B.J.; He, L.X.; Wei, L.; Xie, H.M.; Wang, B.Q.; Li, H.Y.; Chen, X.H.; Zhou, C.M.; Deng, W.W. Etiology and antimicrobial resistance of community-acquired pneumonia in adult patients in China. Chin. Med. J. 2012, 125, $2967-2972$. [PubMed]

6. Eljaaly, K.; Alshehri, S.; Aljabri, A.; Abraham, I.; Al Mohajer, M.; Kalil, A.C.; Nix, D.E. Clinical failure with and without empiric atypical bacteria coverage in hospitalized adults with community-acquired pneumonia: A systematic review and meta-analysis. BMC Infect. Dis. 2017, 17, 385. [CrossRef]

7. Thabit, A.K.; Crandon, J.L.; Nicolau, D.P. Antimicrobial resistance: Impact on clinical and economic outcomes and the need for new antimicrobials. Expert Opin. Pharmacother. 2015, 16, 159-177. [CrossRef]

8. Eljaaly, K.; Botaish, A.; Bahobail, F.; Almehmadi, M.; Assabban, Z.; Thabit, A.K.; Alraddadi, B.; Aljabri, A.; Alqahtani, N.; Aseeri, M.A.; et al. Systematic review and meta-analysis of the safety of erythromycin compared to clarithromycin in adults and adolescents with pneumonia. J. Chemother. 2020, 32, 1-6. [CrossRef] [PubMed]

9. Eljaaly, K.; Alshehri, S.; Bhattacharjee, S.; Al-Tawfiq, J.A.; Patanwala, A.E. Contraindicated drug-drug interactions associated with oral antimicrobial agents prescribed in the ambulatory care setting in the United States. Clin. Microbiol. Infect. 2019, 25, 620-622. [CrossRef] 
10. Aubier, M.; Verster, R.; Regamey, C.; Geslin, P.; Vercken, J.B. Once-daily sparfloxacin versus high-dosage amoxicillin in the treatment of community-acquired, suspected pneumococcal pneumonia in adults. Clin. Infect. Dis. 1998, 26, 1312-1320. [CrossRef]

11. Carbon, C.; Léophonte, P.; Petitpretz, P.; Chauvin, J.P.; Hazebroucq, J. Efficacy and safety of temafloxacin versus those of amoxicillin in hospitalized adults with community-acquired pneumonia. Antimicrob. Agents Chemother. 1992, 36, 833-839. [CrossRef]

12. Léophonte, P.; File, T.; Feldman, C. Gemifloxacin once daily for 7 days compared to amoxicillin/clavulanic acid thrice daily for 10 days for the treatment of community-acquired pneumonia of suspected pneumococcal origin. Respir. Med. 2004, 98, 708-720. [CrossRef] [PubMed]

13. Lode, H.; Garau, J.; Grassi, C.; Hosie, J.; Huchon, G.; Legakis, N.; Segev, S.; Wijnands, G. Treatment of community-acquired pneumonia: A randomized comparison of sparfloxacin, amoxycillin-clavulanic acid and erythromycin. Eur. Respir. J. 1995, 8, 1999-2007. [CrossRef] [PubMed]

14. Lode, H.; Magyar, P.; Muir, J.F.; Loos, U.; Kleutgens, K.; International Gatifloxacin Study Group. Once-daily oral gatifloxacin vs three-times-daily co-amoxiclav in the treatment of patients with community-acquired pneumonia. Clin. Microbiol. Infect. 2004, 10, 512-520. [CrossRef] [PubMed]

15. Petitpretz, P.; Arvis, P.; Marel, M.; Moita, J.; Urueta, J.; CAP5 Moxifloxacin Study Group. Oral moxifloxacin vs high-dosage amoxicillin in the treatment of mild-to-moderate, community-acquired, suspected pneumococcal pneumonia in adults. Chest 2001, 119, 185-195. [CrossRef] [PubMed]

16. Trémolières, F.; de Kock, F.; Pluck, N.; Daniel, R. Trovafloxacin versus high-dose amoxicillin ( $1 \mathrm{~g}$ three times daily) in the treatment of community-acquired bacterial pneumonia. Eur. J. Clin. Microbiol. Infect. Dis. 1998, 17, 447-453. [CrossRef] [PubMed]

17. Postma, D.F.; van Werkhoven, C.H.; van Elden, L.J.; Thijsen, S.F.; Hoepelman, A.I.; Kluytmans, J.A.; Boersma, W.G.; Compaijen, C.J.; van der Wall, E.; Prins, J.M.; et al. Antibiotic treatment strategies for community-acquired pneumonia in adults. N. Engl. J. Med. 2015, 372, 1312-1323. [CrossRef] [PubMed]

18. Farnham, A.; Alleyne, L.; Cimini, D.; Balter, S. Legionnaires' disease incidence and risk factors, New York, New York, USA, 2002-2011. Emerg. Infect. Dis. 2014, 20, 1795-1802. [CrossRef]

19. CDC. Centres for Disease Control and Prevention: Mycoplasma Pneumoniae Infections. Available online: https://www.cdc.gov/ pneumonia/atypical/mycoplasma/about/people-at-risk.html (accessed on 11 January 2021).

20. Sharma, L.; Losier, A.; Tolbert, T.; Dela Cruz, C.S.; Marion, C.R. Atypical Pneumonia: Updates on Legionella, Chlamydophila, and Mycoplasma Pneumonia. Clin. Chest Med. 2017, 38, 45-58. [CrossRef]

21. McCracken, G.H., Jr. Current status of antibiotic treatment for Mycoplasma pneumoniae infections. Pediatr. Infect. Dis. 1986, 5, 167-171. [CrossRef]

22. Mandell, L.A.; Wunderink, R.G.; Anzueto, A.; Bartlett, J.G.; Campbell, G.D.; Dean, N.C.; Dowell, S.F.; File, T.M.; Musher, D.M., Jr.; Niederman, M.S.; et al. Infectious Diseases Society of America/American Thoracic Society consensus guidelines on the management of community-acquired pneumonia in adults. Clin. Infect. Dis. 2007, 44 (Suppl. 2), S27-S72. [CrossRef] [PubMed] 